KENOSIS : JURNAL KAJIAN TEOLOGI

ISSN 2460-6901(Print), 2656-4483 (Online)

https://e-journal.iaknambon.ac.id/index.php/KNS

DOI: $10.37196 /$ kenosis.v7i2.359

\title{
MENYERUPAI ALLAH: Manusia yang Mengaktualisasikan Diri
}

\section{Stephen Rehmalem Eliata}

\author{
Sekolah Tinggi Teologi Reformed Indonesia \\ Jl. Kemang Utara IX No.10 RT.1/RW.1, Duren Tiga, \\ RT.1/RW.1, Duren Tiga, Pancoran, South Jakarta City, Jakarta 12760 \\ stephenrehmalemeliata@gmail.com
}

\begin{abstract}
This paper is a study of the question of how can human beings carry out a call that 'becoming like God'? To answer this question, a construction model of ideas referred to as 'self-actualizing' is mentioned in this paper. It will be presented in two main theses. First, Aquinas's epistemology-metaphysical concept can be a solution to the unclear in understanding the idea of 'becoming like God'. Second, with the participation of Heidegger's thinking on the concept of dasein, mankind can find concrete steps in trying to become like God, namely by actualizing all the potential they have. This paper uses a literature study by examining and analyzing the literature related to the relevant topic. The conclusion in this paper is that the potential that humans have is always in a continuous process to pursue their actuality. This is similar to God Himself who is a pure act.
\end{abstract}

Keywords: Epistemology, Metaphysic, Dasein, Actualization, Becoming

\begin{abstract}
Abstrak
Tulisan ini merupakan sebuah telaah atas pertanyaan bagaimana manusia dapat melaksanakan panggilan 'menyerupai Allah'? Untuk menjawab pertanyaan tersebut, sebuah model konstruksi gagasan yang disebut sebagai 'mengaktualisasikan diri' diajukan dalam tulisan ini. Hal ini akan dipaparkan dalam dua tesis utama, yaitu, pertama, bahwa konsep epistemologi-metafisika tradisi Aquinas dapat menjadi solusi atas kekaburan dalam memahami gagasan tentang 'menyerupai Tuhan'. Kedua, bahwa dengan partisipasi pemikiran Heidegger mengenai konsep dasein, maka manusia dapat menemukan langkah konkret dalam berupaya untuk Menyerupai Allah, yakni dengan mengaktualisasikan segala potensi yang ia miliki. Tulisan ini menggunakan studi pustaka dengan memeriksa dan menganalisis literatur terkait topik yang relevan. Kesimpulan dalam tulisan ini yaitu potensi yang manusia miliki selalu berada
\end{abstract}


dalam sebuah proses terus-menerus untuk mengejar aktualitasnya. Hal tersebut serupa dengan Allah sendiri yang adalah pure act.

Kata kunci: Epistemologi, Metafisika, Dasein, Aktualisasi, Menyerupai

\section{PENDAHULUAN}

Gagasan mengenai 'menyerupai Allah' merupakan panggilan bagi setiap umat Kristen. Sejak mulanya manusia diciptakan sesuai dengan gambar dan rupa Allah, manusia dipanggil untuk secara terus menerus menyerupai Dia. Panggilan Allah itu muncul dalam berbagai ayat di Alkitab. Salah satunya terdapat dalam Imamat 17:2, "Kuduslah kamu, sebab Aku, TUHAN, Allahmu, kudus." Pada ayat ini, Allah memberikan perintah kepada manusia untuk menyerupai Allah di dalam kekudusanNya. Will Bankston dalam artikelnya mencoba membaca ayat ini dalam terang tradisi pemikiran Aquinas. Ia berpendapat bahwa kekudusan Allah dalam ayat tersebut merupakan suatu capaian aktualitas dari kekudusan itu sendiri. Akan tetapi manusia dipanggil untuk menyerupai Allah di dalam aktualitas kekudusan-Nya tidak secara serta-merta, melainkan dengan cara analogis. ${ }^{1}$ Dengan latar belakang pemikiran Aquinas, Bankston dengan tegas memisahkan Allah dari ciptaan. Allah adalah pencipta yang pure act, sedangkan manusia merupakan ciptaan yang berusaha menggerakkan potensinya menjadi aktualitas. Namun dalam artikelnya, Bankston hanya berupaya untuk menawarkan gaya pembacaan Imamat 19:2 dalam tradisi pemikiran Aquinas, dan ia tidak menjelaskan dengan konkret bagaimana manusia dapat menjalankan panggilan untuk menyerupai Allah. ${ }^{2}$

Dalam upaya untuk menjelaskan hal tersebut, terdapat kekaburan yang menghasilkan pandangan teologi yang kurang tepat. Kekaburan itu tersebut disebabkan oleh pandangan epistemologi tertentu yang menyebabkan individu Kristen jatuh di dalam dua titik ekstrim yang berbeda. Titik yang pertama adalah kecenderungan individu Kristen untuk memiliki pemahaman epistemologi yang fundamental. Ia mempercayai akan adanya kebenaran objektif yang Allah telah berikan bagi orang Kristen, yang membawa individu Kristen memeluk gagasan 
Menyerupai Allah dengan lebih statis dan radikal. Sedangkan titik yang kedua adalah kecenderungan individu Kristen (atau umat beragama) untuk memiliki pemahaman epistemologi yang lebih empiris dan saintifik, yang berujung pada penolakan akan keberadaan Allah di dunia (atau dikenal dengan istilah anti-metafisika). ${ }^{3}$ Keduanya merupakan sebuah pandangan epistemologi yang ekstrem, yang dapat mengaburkan gagasan mengenai menyerupai Allah.

Untuk menjawab kekaburan ini, maka sebuah model yang berbeda diajukan dalam tulisan ini. Pertama, konsep epistemologi-metafisika Aquinas dapat menjadi solusi atas kekaburan yang muncul dari dua kelompok ekstrem tersebut. Setiap individu dipanggil untuk Menyerupai Allah melalui sebuah proses Becoming yang tak terbatas. Proses ini memanggil individu untuk mengaktualisasikan diri melalui penyingkapan diri Allah dalam dunia materi. Kedua, dengan meminjam konsep dasein oleh Heidegger, individu Kristen dapat semakin menghayati bahwa terdapat aspek individualitas dalam gagasan 'menyerupai Allah'. Aspek ini membuat individu menyadari bahwa proses becoming itu terjadi dalam dirinya melalui segala potensi yang ia miliki secara primordial. Dengan kedua pendapat di atas, maka tulisan ini berusaha untuk mengonstruksikan sebuah gambaran mengenai gagasan menyerupai “Allah”, yang mampu dielaborasi menjadi manusia yang mengaktualisasikan diri.

Konstruksi makna baru dari 'menyerupai Allah' dalam tulisan ini merupakan alternatif lain dalam menghayati dan mengaplikasikan ajaran Kristen mengenai Imitatio Dei. Konstruksi ini meletakan dasar untuk penghayatan kembali menyerupai Allah dalam dua hal secara bersamaan, yaitu pada ranah praxis, dan juga dihayati dengan adanya interaksi antara pewahyuan Allah dan 'kedalaman' diri masing-masing individu Kristen. Imitatio Dei bukan lagi menjadi sebuah hukum yang statis berdasarkan pada pewahyuan Allah melalui Alkitab, namun dapat menjadi sebuah ajaran yang dinamis, unik dan khusus berdasarkan setiap pribadi-pribadi Kristen.

\section{METODE PENELITIAN}


Tulisan ini merupakan studi pustaka, dengan melakukan analisis atas literaturliteratur ilmiah atas diskusi filosofis topik terkait. Langkah-langkah yang dilakukan untuk menjelaskan hasil analisis adalah, pertama-tama menjelaskan terlebih dahulu kekaburan gagasan mengenai 'menyerupai Allah' yang disebabkan oleh konsep epistemologi tertentu. Kedua, uraian untuk menjawab kekaburan tersebut dengan memaparkan pemikiran epistemologi-metafisika Aquinas yang akan menjelaskan adanya proses becoming dalam menghayati gagasan ini. Ketiga, berisikan pemaparan pemikiran ontologi Heidegger melalui konsep dasein, untuk menjelaskan aspek individualitas dalam mengaktualisasikan diri. Yang keempat, usaha untuk konstruksi dari kedua pemikiran tersebut untuk dapat menghasilkan model konstruktif yang kontekstual.

\section{HASIL DAN PEMBAHASAN}

\section{Kekaburan mengenai Gagasan Menyerupai Allah}

Kaburnya pemahaman tentang gagasan menyerupai Allah dapat dijelaskan ke dalam dua kelompok yang berbeda. Pertama, adalah kelompok yang memiliki pemahaman epistemologi yang fundamental. Kelompok ini sering disebut sebagai kelompok fundamentalis. Seorang sejarawan berpendapat bahwa kelompok fundamentalis ini berasal dari kelompok Old Princeton yang muncul pada abad 19. ${ }^{4}$ Berdasarkan analisa Helseth, kelompok ini dipengaruhi oleh filsafat abad pencerahan yang memberi ruang yang luas untuk penggunaan rasio. Salah satu representasi pendekatan ini hadir dalam esai B. B. Warfield yang berpendapat bahwa manusia memiliki kapasitas rasio untuk menilai segala sesuatu berdasarkan kebenaran dari iman Kristen. ${ }^{5}$ Pemikiran ini mendorong kelompok fundamentalis untuk membentuk sebuah konsep epistemologi yaitu bahwa kebenaran objektif dapat dimiliki melalui kapasitas rasio manusia. Di samping itu, dengan pengaruh dari Scottish Philosophy, kelompok ini mempercayai bahwa kebenaran itu objektif dan hadir dalam kesatuan. ${ }^{6}$ Konsep inilah yang melengkapi konsep epistemologi kelompok fundamentalis yang melihat sebuah kebenaran sebagai kebenaran yang tunggal dan rasional, yang mampu dimiliki oleh umat Kristen melalui kapasitas rasionya. 
Di dalam kerangka pemikiran ini, gagasan Menyerupai Allah dipahami dengan lebih radikal. Kepercayaan bahwa kebenaran bersifat objektif dan mampu dimiliki oleh manusia dengan sepenuhnya, membuat kelompok ini menciptakan sebuah pemahaman yang lebih statis. Kelompok fundamentalis mengidentikkan kebenaran objektif dengan Alkitab, yang menyebabkan mereka melandaskan gambaran Allah dengan pendekatan yang lebih literal terhadap Alkitab. Menyerupai Allah dipahami dengan berupaya mengikuti sikap dan tindakan yang Allah lakukan sesuai catatan Alkitab. Hal ini yang menjadi masalah utama dari kelompok fundamentalis. Susabda dalam bukunya menyingkapkan permasalahan ini, yaitu bahwa Menyerupai Allah tidak dapat dilakukan secara noumenological. Segala sikap dan tindakan Allah yang dicatat dalam Alkitab hadir dalam bentuk phenomenological yang tidak secara langsung menyingkapkan kebenaran tersebut. ${ }^{7}$

Selain permasalahan epistemologi, terdapat permasalahan lain dari kelompok ini. Penelitian empiris menunjukkan bahwa kelompok yang mempercayai adanya kebenaran objektif yang mereka dapat miliki, cenderung untuk memiliki tingkat selfrighteous dan ethnocentrism yang tinggi. ${ }^{8}$ Penelitian lainnya juga menemukan bahwa kelompok dengan kategori fundamental cenderung untuk memiliki sikap agresif dan berseteru dengan kelompok agama lain. ${ }^{9}$ Dua penelitian empiris ini menunjukkan bahwa pemahaman agama yang lebih fundamental justru membawa kepada sikap dan perilaku yang merugikan. Pandangan ini justru menciptakan sebuah budaya yang tertutup, egois dan merendahkan kelompok lain.

Pada titik ekstrem yang berlawanan terdapat kelompok yang memiliki pandangan epistemologi yang lebih empiris yang berujung pada penolakan akan keberadaan Allah. Dalam artikelnya, Scott menemukan bahwa pemikiran ini mulai berkembang pada era modern. ${ }^{10}$ Semangat pemikiran empiris ini tidak lepas dari pengaruh pada masa sebelumnya yaitu filsafat renaisans yang mengutamakan otonomi dalam berpikir sehingga membawa perubahan yang pesat pada ilmu pengetahuan. Pengaruh tersebut dapat dilihat dari pemikiran Francis Bacon - yang membarui ilmu pengetahuan - ia menyatakan bahwa seluruh keberadaan harus dapat didefinisikan melalui persepsi, fenomena fisik dan dapat dibuktikan secara empiris. ${ }^{11}$ Pemikiran Bacon kemudian mempengaruhi pemikir-pemikir lainnya seperti Isaac Newton, David 
Hume dan Auguste Comte yang mereduksi kebenaran pada bukti empiris. Penekanan pada bukti-bukti empiris membawa para pemikir ini untuk menghayati sebuah dunia yang anti-Allah (atau anti-metafisika). ${ }^{12}$ Kesimpulan ini didapatkan karena keberadaan Allah yang metafisika tidak dapat dijelaskan secara empiris, oleh sebab itu para pemikir ini lebih mempercayai akan keberadaan fisik yang dapat dibuktikan secara empiris.

Pada abad 20, terdapat filsuf-filsuf yang memelopori pemikiran metafisika baru. Jika pada masa sebelumnya kelompok empiris menolak keberadaan Allah yang tidak dapat dibuktikan secara empiris, Heidegger mengajukan sebuah pemikiran yang sedikit berbeda. Heidegger tidak menolak keberadaan Allah. Ia mempercayai akan keberadaan 'Being' sebagai penyebab dari 'beings', akan tetapi karena 'Being' tidak hadir dalam keberadaan yang empiris, maka manusia sebagai 'beings' diajak untuk memulai memutus hubungan dengan ide mengenai Allah. ${ }^{13}$ Pemikiran Heidegger ini kemudian mempengaruhi seorang filsuf yaitu Jean-Luc Marion. Marion berpendapat bahwa ilmu Teologi harus mulai menghapus konsep mengenai Allah, karena iman tidak membutuhkan Subjek tertentu untuk menjadi objeknya. Umat Kristen diajak untuk mulai memberikan sikap 'silence' ketika berbicara mengenai Allah. ${ }^{14}$

Pada kelompok yang kedua ini, konsep epistemologi yang lebih empiris dengan optimis telah meniadakan keberadaan Allah. Pemikiran tersebut dikembangkan dengan lebih mutakhir di dalam konsep metafisika oleh para pemikir setelahnya (Nietzsche, Heidegger dan Marion). Di dalam pemahaman seperti ini, umat Kristen tidak memiliki teladan untuk menyerupai sang Ilahi. Umat Kristen diajak untuk menjalani hidupnya secara mandiri tanpa harus memikirkan adanya keberadaan yang Ilahi di luar dunia yang tampak. Kedua titik ekstrem ini menjadi bukti kekaburan dalam memahami panggilan individu Kristen untuk Menyerupai Allah. Tulisan ini melihat pemahaman epistemologi yang tidak tepat akan mempengaruhi konsep metafisikanya. Kesalahan pada konsep metafisika akan mengaburkan gambaran Allah dalam kepercayaan Kristen, yang seharusnya menjadi teladan bagi setiap umat Kristen untuk menjadi seperti dengan-Nya (Roma 8:12). 


\section{Epistemologi-Metafisika Aquinas}

Thomas Aquinas merupakan seorang teolog dan filsuf besar abad pertengahan. ${ }^{15}$ Pemikiran metafisikanya tidak dapat dipisahkan dari konsep epistemologi yang ia miliki, terutama konsep epistemologi tradisi Agustinian. Dalam meresepsi epistemologi Agustinus, Aquinas merekatkan pemikiran tersebut dengan filsafat Aristoteles sehingga ia membentuk sebuah konsep yang baru. ${ }^{16}$ Sebuah konsep epistemologi yang berkaitan erat dengan konsep metafisikanya, yaitu konsep Analogia Entis (Analogy of Being).

\section{Analogia Entis (Analogy of Being)}

Konsep Analogia Entis dari Aquinas berangkat dari pemikiran epistemologi Agustinus mengenai tanda (sign) dan yang ditandai (thing) yang bertujuan untuk mencapai sebuah kesimpulan metafisika, yaitu pengetahuan tentang Allah. Agustinus berpendapat bahwa semua tanda menunjuk kepada sesuatu yang ditandai, kemudian yang ditandai juga akan menunjuk kepada sesuatu yang ditandai pula. Proses ini terus berlangsung hingga menemukan sebuah tanda yang tidak menandai apa-apa, yaitu adalah Allah sendiri. ${ }^{17}$ Di dalam konsep epistemologi ini, Agustinus memulainya dengan proses epistemis yang empiris. Ia menekankan akan fungsi dari pancaindra manusia untuk menangkap tanda-tanda yang bersifat indrawi. Dari titik ini maka mulai ada pergerakan kepada Sang Penanda itu, yaitu Allah itu sendiri. ${ }^{18}$

Aquinas dengan lugas meresepsi pemikiran epistemologi Agustinus dan kemudian mengembangkannya lebih lanjut. Aquinas meninggalkan pemikiran Agustinus yang dualistis antara tubuh dan jiwa, pancaindra dan rasio, serta dunia materi dan imateri. ${ }^{19}$ Aquinas berpendapat bahwa seluruh ciptaan yang bersifat materi merupakan pewahyuan dari Sang Ilahi yang bersifat imateri, dan keduanya memiliki ikatan yang erat. Oleh sebab itu, bagi Aquinas memahami dunia materi juga dapat berarti memahami yang imateri, dengan kata lain proses memahami tentang Allah dapat dilakukan melalui ciptaan yang bersifat materi.

Proses epistemis ini dimulai dari dunia materi terlebih dahulu. Pancaindra manusia mengambil peran paling awal yaitu untuk menangkap segala pengetahuan yang bersifat indrawi. Kemudian fungsi intellect manusia memrosesnya untuk 
menangkap kebenaran yang didapatkan dari pengetahuan indrawi tersebut. Kebenaran yang didapatkan kemudian menempati posisi sebagai analogi, yang menjadi analogi terhadap kesempurnaan Allah yang merupakan penyebab dari kebenaran yang telah didapatkan tersebut. ${ }^{20}$ Oleh sebab itu, terdapat dua kesimpulan mula-mula terhadap pemikiran ini. Yang pertama, yaitu bahwa seluruh ciptaan dapat menjadi analogi terhadap kesempurnaan Allah; yang kedua, yaitu bahwa kebenaran yang hadir dalam ciptaan disebabkan oleh Allah yang merupakan Prima Causa (the first cause).

Kesimpulan ini tidak dapat dilepaskan dari konsep metafisika Aquinas. Aquinas berpendapat bahwa Allah adalah satu-satunya Being yang sempurna. Di dalam tradisi pemikiran filsafat Aristotelian, Aquinas mengatakan bahwa Allah adalah Actus Purus (the Pure Act). Segala potensi yang ada dalam diri-Nya telah teraktualisasikan dengan sempurna. Karena Ia adalah yang sempurna, maka Ia dapat menjadi penyebab dari ciptaan. $^{21}$ Contohnya, di dalam dunia ini kita dapat menemukan suatu keindahan dari ciptaan. Namun hal tersebut tidak dapat dilepaskan dari Allah, yaitu karena Allah memiliki keindahan yang sempurna maka ciptaan dapat memiliki keindahan juga.

Gambaran mengenai Allah sebagai Actus Purus membawa kepada pemahaman yang lebih jelas mengenai gagasan menjadi seperti Allah. Konsep ini menggambarkan sosok Allah yang sempurna di dalam diri-Nya. Tidak ada satu potensi yang tidak menjadi aktualitas-Nya. Sedangkan manusia sebagai ciptaan ada pada sisi yang berseberangan. Manusia memiliki banyak potensi yang belum menjadi aktualitasnya. Oleh sebab itu, di dalam penghayatan akan Allah yang sebagai Actus Purus, manusia dipanggil untuk selalu mengejar kesempurnaan aktualitas Allah melalui segala potensi yang ia miliki.

Satu-satunya cara untuk mengejar aktualitas Allah adalah dengan jalan mencari kebenaran Allah melalui konsep Analogia Entis. Berdasarkan apa yang sudah dipaparkan di atas, dalam upayanya Menyerupai Allah, manusia harus melewati proses epistemis melalui fungsi dari pancaindra dan intellect-nya yang berusaha meraih kebenaran Allah melalui dunia ciptaan. Kebenaran yang telah diraih memiliki sifat sebagai analogi terhadap kesempurnaan Allah, maka berdasarkan pemahaman tersebut manusia akan menggerakkan potensinya, di dalam lingkup kebenaran yang 
telah didapatkan, untuk mengejar kesempurnaan seperti Allah yang telah sempurna. Contohnya, ketika manusia telah melewati proses epistemis melalui ciptaan, dan meraih sebuah kebenaran Allah yaitu bahwa Allah adalah sempurna bijaksana, maka manusia dipanggil untuk menggerakkan segala potensi yang ia miliki untuk menyerupai Allah yang sempurna bijaksana tersebut.

Akan tetapi penjelasan ini tidak cukup untuk membawa kepada pemahaman yang lebih utuh mengenai konsep metafisika Aquinas. Untuk itu, perlu untuk menjelaskan mengenai keunikan pemikiran metafisika Aquinas dibanding pemikir sebelumnya, yaitu melalui pembedaan Esensi dan Eksistensi.

\section{Esensi dan Eksistensi}

Etienne Gilson mengatakan bahwa pemikiran Aquinas mengenai pembedaan antara esensi dan eksistensi telah mereformasi pemikiran teologi dan ontologi pada masa itu. ${ }^{22}$ Leo J. Elders memperkuat pendapat Gilson dengan mengatakan bahwa pembedaan mengenai esensi dan eksistensi tidak muncul dengan jelas dalam pemikiran Bapa Gereja sebelum Aquinas. Dalam analisa terhadap keterkaitan pemikiran antara Aquinas dan Agustinus, Elders mengatakan "Did Augustine know the real distinction between essence or creatures and their act of being? The answer appears to be that in certain of his writings he is groping toward this distinction.",23

Dalam konsep metafisikanya, Aquinas mengatakan bahwa eksistensi merupakan dampak dari esensi dari being. Dalam pemikiran Aquinas, eksistensi dapat disebut juga dengan act of being atau tindakan mengada. Being di dalam tindakan mengadanya selalu berusaha untuk memenuhi esensinya. ${ }^{24}$ Jika konsep ini dikenakan kepada Allah maka kita dapat mengatakan bahwa esensi Allah adalah tindakan mengada-Nya sendiri. Keindentikan keduanya diturunkan dari konsep mengenai Allah sebagai Pure Act, yaitu karena Allah memiliki esensi yang sempurna sebagai Pure Act, maka dapat disimpulkan bahwa tindakan mengada-Nya telah sempurna mencapai kepada esensi-Nya. Akan tetapi, pembedaan antara esensi dan tindakan mengada juga memiliki implikasi yang signifikan terhadap konsep Analogia Entis yang telah dibahas pada bagian sebelumnya. 
Aquinas mengatakan bahwa segala bentuk kebenaran dari dunia materi hanya dapat mencapai pada pembuktian akan tindakan mengada atau eksistensi Allah. ${ }^{25}$ Ketika kita memandang alam yang indah, kebenaran mengenai keindahan tersebut hanyalah menjadi sebuah analogi yang membuktikan bahwa terdapat pribadi yang sempurna indah, yaitu adalah Allah. Aquinas dengan tegas memisahkan esensi Allah dari dunia materi. Segala bentuk ciptaan hanya mampu untuk menyatakan keberadaan Allah, namun tidak pernah membuat manusia memahami esensi Allah.

Rooney memberikan tanggapan mengenai pemikiran Aquinas ini dengan mengatakan "following from our epistemic limits in not being able to know God's essence (in this life), all our human concepts of any determinate 'property' are defective when applied to what God is in himself (deficit a modo quo Deus in se est). ${ }^{26}$ Di dalam ketidakmampuan manusia memahami Allah dengan utuh, Analogia Entis menjadi sebuah kemungkinan solusi paling baik bagi manusia untuk memahami Allah. Rocca memahami akan keterbatasan manusia ini dan memberikan sebuah jalan bagi manusia untuk mengenal Allah yaitu melalui tindakan mencari dan menghasrati kebenaran yang ada di dunia materi. ${ }^{27}$ Konsep ini akan mendasari bagian selanjutnya yang akan mengambil posisi klimaks dalam menjelaskan gambaran Allah dalam gagasan menjadi seperti Allah.

\section{Degree of Being}

Konsep Aquinas mengenai Analogia Entis tidak meniadakan peran dunia materi. Justru bagi Aquinas, manusia dapat mengenal Allah melalui analogi-analogi yang dapat ditemukan dalam dunia materi. Dalam Summa Theologica, Aquinas mengatakan,

For, we cannot name God except from creatures, as was said above. And thus, whatever is said about God and creatures is said according as there is some order of the creature to God as to a principle and cause in which all the perfections of things pre-exist excellently. ${ }^{28}$

Aquinas menunjukkan adanya keterikatan yang erat antara ciptaan dengan Allah. Allah dipandang sebagai keberadaan yang paling tinggi (Higher Being) dan sempurna (Perfect) di dalam aktualitasnya, sedangkan manusia sebagai ciptaan ada di 
dalam dunia materi yang masih berupaya untuk menggerakkan potensinya menuju kepada aktualitasnya. Aquinas mengenakan atribut Higher Being kepada Allah, yang secara niscaya memunculkan sebuah kategori tingkatan (degree). ${ }^{29}$ Adanya penggunaan kata Higher, secara tidak langsung menunjukkan adanya keberadaan yang Lesser Being. Jika Higher Being dikenakan kepada Allah, maka Lesser Being menjadi atribut bagi manusia. Kaitan yang erat antara keduanya dijelaskan oleh Aquinas dalam kategori Degree of Being. ${ }^{30}$ Gilson memberi tanggapan terhadap pemikiran Aquinas ini dengan mengatakan,

This invited Thomas to think of the universe as arranged in a hierarchy according to the various possible degrees of finite participation in the causality of the first cause, in the actuality of the unmoved mover, in the goodness of pure goodness, in the nobility of the purely noble, and in the truth of pure truth. ${ }^{31}$

Manusia yang adalah ciptaan, yang keberadaannya disebabkan oleh keberadaan Allah yang sempurna, ditempatkan dalam sebuah garis Being dan senantiasa berpartisipasi dalam kesempurnaan Allah, di mana manusia memiliki arah untuk menjadi sempurna seperti Allah yang sempurna. Pemikiran Aquinas menghasilkan sebuah imaji untuk manusia terus bergerak kepada Allah di dalam sebuah lintasan Being dengan jarak yang tak terhingga. Ke-tak terhingga-an dari jarak ini disebabkan oleh manusia yang tidak pernah sanggup meraih dan memiliki esensi dari Allah. Jadi, selama manusia hidup dalam dunia materi, manusia akan terus berusaha untuk memahami dan mengenal Allah melalui eksistensi-Nya yang dinyatakan melalui ciptaan, dan manusia juga dipanggil untuk menjadi seperti dengan Allah dalam arti untuk menjadi sempurna dalam segala potensi yang manusia miliki dalam dunia materi.

Aquinas menggunakan tiga kata dalam tulisannya, yaitu viatores, rationes dan comprehensores. Aquinas menggambarkan manusia sebagai viatores atau pengembara yang hidup dalam dunia ciptaan. Manusia dipanggil untuk menggunakan rationes atau intellect-nya untuk mengenal Allah melalui menghasrati kebenaran Allah yang ada di balik ciptaan. Manusia menggunakan rationes dengan sebuah metode yang khusus, yaitu metode analogi, karena ketidakmampuan ciptaan untuk memiliki esensi Allah. Di dalam aktivitas analogi yang dilakukan viatores menggunakan rationes nya, 
Aquinas mengatakan bahwa manusia memiliki tujuan akhir untuk comprehensores segala kebenaran yang telah didapatkan untuk dapat mengenal Allah dengan lebih utuh. ${ }^{32}$ Pada akhirnya, segala comprehensores yang manusia raih merupakan sebuah panggilan dari Allah bagi manusia untuk secara terus menerus mengusahakan kesempurnaan seperti Allah, menggerakkan potensinya untuk menuju kepada aktualitas dirinya.

\section{Implikasi Konsep Epistemologi-Metafisika Aquinas}

Uraian mengenai konsep epistemologi-metafisika dari Aquinas pada bagian sebelumnya dapat menjadi salah satu jalan untuk menyingkap sekaligus menjembatani pandangan epistemologi yang terkadang begitu ekstrem.

Aquinas memulai konsep metafisikanya dari penjelasan yang bersifat epistemis. Ia bahkan menganut epistemologi yang lebih empiris sama seperti para filsuf modern (Francis Bacon, Aguste Comte, Isaac Newton, dsb.). Akan tetapi, pemikirannya tidak membawanya untuk menjadi seorang yang anti-metafisika. Perbedaan antara pemikiran Aquinas dengan para filsuf modern terletak pada keterkaitan antara dunia materi dengan Allah. Para filsuf modern cenderung untuk memisahkan dengan tegas antara dunia materi dengan keberadaan Allah yang bersifat imateri, dan mereduksi segala kebenaran ke dalam proses epistemis yang empiris. Sebagai umat Kristiani, kita tidak dapat meniadakan keberadaan Allah sekalipun Ia tidak hadir dalam wujud yang materi. ${ }^{33}$ Scott berpendapat bahwa pilihan ini bukan menjadi pilihan yang seharusnya diambil oleh umat Kristen. Sejak mulanya, umat Kristen bertumbuh dari kehidupan agama yang mempercayai akan keberadaan yang Ilahi di luar dunia materi, ${ }^{34}$ oleh sebab itu pemikiran Aquinas ini dapat menjadi pelengkap terhadap epistemologi empiris.

Di lain pihak, konsep epistemologi-metafisika Aquinas juga menolak kepercayaan kelompok fundamentalisme. Penghayatan akan konsep Aquinas ini membawa setiap umat beragama untuk memahami bahwa manusia tidak akan pernah memiliki kebenaran Allah dengan tuntas selama hidup di dunia. Umat Kristen diajak untuk merefleksikan bahwa ia adalah satu orang dari sekian banyaknya umat Kristen lainnya yang berusaha mengenal Allah dan kebenaran-Nya. Refleksi seperti ini justru 
yang dapat mempengaruhi umat Kristen untuk menjadi umat beragama yang rendah hati, mengenali keterbatasan diri, dan terbuka untuk mendengar pandangan umat Kristen yang berlainan. Dalam konsep Aquinas ini, kebenaran dibayangkan sebagai kebenaran bagi semua umat Kristen yang tidak terbatas pada kelompok tertentu. Selain itu, adanya sebuah usaha yang terjadi secara terus menerus dalam menjadi seperti Allah, membuat umat Kristen menyadari bahwa dirinya sedang berada di dalam sebuah proses becoming. Proses becoming ini yang seharusnya menjadi ciri khas umat Kristen, yang dengan niscaya menolak kepercayaan dari kelompok fundamentalis.

\section{Heidegger: Dasein dan Resoluteness}

Heidegger merupakan seorang filsuf yang memberikan makna baru dalam locus ontologi. Pemikirannya hadir sebagai anti-tesis terhadap pemikiran ontologi sebelumnya, yaitu oleh Descartes. Pemikiran kedua tokoh ini didasarkan pada pemisahan yang tegas antara esensi dan eksistensi, namun dibahasakan dengan berbeda. Descartes mengatakan bahwa eksistensi manusia akan hadir ketika manusia dapat meraih esensinya melalui aktivitas meragu-ragukan (res cogitans). ${ }^{35}$ Sedangkan Heidegger membahasakannya ke dalam kata Dasein yang diartikan sebagai being-inthe-world, sebuah kenyataan manusia terlempar untuk ada di bumi. Dasein dapat dicapai melalui sebuah proses unik dalam diri yang ia sebut sebagai resoluteness. ${ }^{36}$

\section{Dasein}

Konsep Dasein sangat terkait dengan pemahaman Heidegger mengenai realitas. Dalam bukunya, Being and Time (1953), Heidegger memisahkan realitas menjadi dua, yaitu Sein dan Seindes. Yang pertama dapat diartikan sebagai 'Ada', dan yang kedua dapat diartikan sebagai 'Mengada'. ${ }^{37}$ Keduanya memiliki tingkatan yang berbeda. Seluruh ciptaan dapat dikatakan 'Mengada', namun belum tentu 'Ada'. Hardiman mengatakan bahwa bagi Heidegger,

'Ada' jelas bersifat paling umum, tetapi bukan sekadar cakupan yang paling lias dari segala cakupan. Keumuman 'Ada' melampaui segala keumuman cakupan. Ada menopang Mengada-mengada dan memungkinkan Mengada-mengada ada. Ada bersifat transendental. ${ }^{38}$ 
Pemikiran ini yang melandasi konsep Dasein dari Heidegger, yaitu bahwa Dasein merupakan kondisi ketika individu menanyakan ke-'Ada'-an-nya, yang melampaui ke-'Mengada'-an-nya. Kesadaran akan ke-'Ada'-an-nya membuat individu mengakses dirinya dengan lebih utuh dalam kaitannya dengan kehidupan yang ia jalani. Kondisi ini dapat membuat individu mulai melihat dirinya serta segala aspek di dalamnya, yang secara niscaya telah terlempar dan berada di tengah dunia yang ia hidupi. ${ }^{39}$ Jadi bagi Heidegger, manusia yang terlempar di tengah dunia tidak serta merta memiliki ke-'Ada-an-nya, melainkan manusia harus mengusahakan kondisi tersebut untuk mencapai eksistensinya. Manusia yang mengusahakan eksistensinya berarti ia harus mengakses dirinya di dalam intensi yang lebih mendalam dari ke-'Mengada'-an-nya, dan berelasi dengan dirinya yang hadir dalam keterlemparan tersebut. ${ }^{40}$

Konsep ini berarti eksistensi manusia bukan merupakan sesuatu yang sudah dimiliki, melainkan sebuah potensi yang perlu diusahakan untuk menjadi aktual. Hal tersebut dapat ditarik dalam konteks menjadi umat Kristen. Eksistensi individu Kristen di dalam menghayati panggilannya menjadi seperti Allah tidak serta merta sudah terjadi, melainkan individu Kristen juga dipanggil untuk mengusahakan eksistensinya sendiri yaitu dengan mengakses dan berelasi dengan ke-'Ada'-an-nya. Di dalam relasi ini, maka individu Kristen dapat menghayati proses menjadi seperti Allah dengan keutuhan diri sebagaimana keadaan dirinya. Susabda sependapat dengan gagasan ini. Ia mengajukan sebuah konstruksi Teologi bagi individu Kristen yang dapat mencakup keseluruhan dan ke-Allah dirinya. ${ }^{41}$ Oleh sebab itu, konsep Dasein ini mengajak individu Kristen untuk senantiasa mengusahakan eksistensinya, di dalam interaksi dan relasi dengan ke-'Ada'-an-nya, di dalam upaya untuk menjadi seperti Allah.

\section{Resoluteness}

Konsep Dasein dari Heidegger tidak berhenti sampai di sana. Ketika individu sudah mampu untuk berinteraksi dan berelasi dengan ke-'Ada'-an-nya, maka individu tersebut mulai mengenali dirinya secara utuh. Akan muncul berbagai potensi-potensi 
dalam diri yang perlu diaktualisasikan sesuai dengan keberadaannya di tengah dunia (atau lingkungan tempat ia berada). Pada titik ini individu ditantang untuk mengambil sebuah keputusan terhadap suatu tindakan. Heidegger menyebut proses ini dengan istilah resoluteness. Keputusan tersebut mencakup suatu potensi yang ia miliki secara primordial, dan kini ia rengkuh untuk menggerakkan potensi yang ia miliki untuk diaktualisasikan. ${ }^{42}$ Jadi, bagi Heidegger, resoluteness merupakan suatu tindakan yang pertama-tama telah mempertimbangkan keberadaan individu di tengah dunia yang ia tinggali, kemudian ia mempertimbangkan mengenai potensi yang ia telah miliki secara primordial, serta ia juga mengambil keputusan dan tindakan menuju kepada aktualisasi dari keputusannya tersebut.

Adanya pertimbangan-pertimbangan yang dilakukan oleh individu dalam interaksinya dengan ke-'Ada'-an-nya, membawa konsep Dasein dari Heidegger kepada pembahasan hermeneutis. Hardiman menyebutkan bahwa bagi Heidegger manusia adalah makhluk hermeneutis. Ketika manusia mampu untuk membuka keberadaannya, maka ia sejatinya sedang berupaya menangkap apa yang hadir dalam faktisitas, dan melihat akan kemungkinan-kemungkinan bagi dirinya untuk berada. ${ }^{43}$ Bagi Heidegger, proses hermeneutis bukanlah tentang menangkap suatu informasi, melainkan sebuah persoalan yang lebih mendasar, yaitu mengenai eksistensi. ${ }^{44}$ Jadi sebagai makhluk yang terlempar di dalam dunia, manusia sebagai makhluk hermeneutis bukan memiliki tujuan untuk membuka dunia, melainkan membuka dasein terhadap dunia, yaitu segala potensi yang ia miliki untuk mengarahkannya kepada tindakan yang dapat membawa manusia kepada proses aktualisasi dirinya

\section{Manusia yang Mengaktualisasikan Diri}

Penjelasan tentang epistemologi Aquinas menunjukkan bahwa terdapat jarak yang tak terhingga antara manusia sebagai ciptaan, dengan Allah yang adalah Pencipta. Individu Kristen yang hidup di tengah dunia tidak pernah dapat mengenali dan memiliki esensi Allah secara utuh, yang berarti individu Kristen tidak akan pernah memiliki kebenaran itu sendiri. Dari pemahaman ini, maka Menyerupai Allah bukan sebuah tindakan yang terjadi satu kali saja, melainkan selama manusia masih hidup 
dalam dunia materi, manusia akan terus berada dalam sebuah proses untuk menjadi seperti Allah. Untuk itu, dalam konstruksi ini menggunakan kata 'Becoming' dalam menjelaskan konsep tersebut.

Apa yang dilakukan dalam proses 'Becoming'? Individu Kristen diajak untuk melakukan proses pencarian - seperti yang disebut oleh Aquinas sebagai viatores yaitu berusaha untuk meraih kebenaran Allah dalam dunia materi. Didasarkan pada pemikiran epistemologi Aquinas, maka manusia dapat dikatakan mampu untuk meraih kebenaran Allah di dalam dunia materi yaitu melalui proses epistemologi. Proses ini dalam pemikiran Aquinas disebut sebagai analogia entis, yang dilakukan dengan membentuk analogi-analogi yang diraih dari dunia materi. Jadi, ketika individu Kristen memandang dunia materi, maka melalui analogi-analogi tersebut individu Kristen mampu untuk meraih kebenaran Allah (atau atribut Allah). Kebenaran Allah tersebut yang kemudian dimasukkan ke dalam proses 'menyerupai Allah', yaitu memiliki tujuan akhir untuk mengaktualisasikan diri terhadap kebenaran Allah tersebut. Akan tetapi dalam tulisan ini menyertakan pemikiran Heidegger mengenai konsep Dasein yang memberikan pemaknaan yang menjadi berbeda.

Sebelum individu Kristen masuk dalam proses epistemologi (berdasarkan pemikiran Aquinas), individu tersebut harus memenuhi suatu persyaratan kondisi khusus. Persyaratan tersebut adalah kondisi di mana individu hadir di dalam interaksi dan relasi terhadap ke-'Ada'-an-nya. Konsep ini mengartikan bahwa terdapat faktor subjektivitas atau individualitas dari individu yang telah hadir di dalam diri secara primordial. Pemikiran Heidegger ini membuka ruang pada penghargaan terhadap nilai-nilai subjektif yang dimiliki oleh individu. Kondisi ini yang perlu dipenuhi terlebih dahulu sebelum individu Kristen memulai proses pencariannya terhadap kebenaran Allah di dunia materi ini. Oleh sebab itu, pemikiran dari Heidegger ini yang menyeimbangkan pemikiran Aquinas, yaitu di dalam menyerupai Allah terdapat aspek subjektivitas, yaitu penerimaan terhadap nilai-nilai primordial individu, dan aspek objektivitas, yaitu kebenaran Allah melalui analogi dunia materi.

Heidegger dan Aquinas mengajak individu untuk masuk di dalam proses aktualisasi diri. Namun di dalam konstruksi ini menyediakan ruang bagi keduanya untuk saling berinteraksi. Ketika sang Dasein itu mencari kebenaran Allah melalui 
dunia materi, maka di sana akan ada interaksi antara nilai-nilai subjektif yang individu tersebut miliki, dan kebenaran Allah yang terungkap melalui dunia materi. Interaksi ini merupakan sebuah titik pertemuan yang kudus dan suci, di mana segala subjektivitas individu kini bersentuhan dengan kudusnya kebenaran Allah. Hasil akhir dari interaksi ini adalah sebuah keputusan terhadap suatu tindakan tertentu yang mengarahkan potensi individu Kristen terhadap aktualitasnya. Proses ini akan berjalan secara terus menerus. Individu yang berada di dalamnya dipanggil untuk bergerak ke luar dan ke dalam. Keluar dalam arti mencari kebenaran Allah di balik dunia materi, namun juga ke dalam, dalam arti berinteraksi dengan ke dalaman dari diri, yang keduanya memiliki tujuan untuk aktualisasi diri sebagai bentuk menyerupai Allah.

\section{KESIMPULAN}

Konsep epistemologi dari Aquinas dapat menjadi solusi terhadap kekaburan dalam konsep epistemologi dari dua titik ekstrem yang telah dibahas. Konsep Aquinas ini mengajak setiap individu Kristen untuk rendah hati dan terbuka terhadap kebenaran Allah yang sudah atau/dan telah dimiliki oleh individu Kristen. Setiap individu Kristen berada dalam sebuah proses Becoming yang tiada henti selama berada dalam dunia materi. Kebenaran Allah tidak pernah dimiliki, akan tetapi menjadi kebenaran yang terus dikejar oleh manusia. Dengan partisipasi diskusi dari pemikiran Heidegger, tulisan ini mengonstruksikan sebuah konsep yang lebih berimbang antara aspek subjektivitas dan objektivitas di dalam proses Menyerupai Allah. Heidegger yang menghargai aspek subjektivitas manusia, membuka ruang untuk dapat berinteraksi antara subjektivitas manusia dan objektivitas kebenaran Allah. Oleh sebab itu ,hanya di dalam interaksi keduanya, setiap individu Kristen dipanggil untuk mengaktualisasikan dirinya menuju kepada kebenaran Allah yang telah diraihnya melalui dunia materi. Dengan itu, proses Menyerupai Allah menjadi proses yang tiada henti dalam interaksi antara manusia dengan Allah, dan interaksi manusia dengan dirinya untuk mewujudkan aktualisasinya. 


\section{Endnotes:}

${ }^{1}$ Will Bankston, "'You Shall Be Actualized, for I Am Pure Actuality': Holiness and the Perfecting Relation of Grace," International Journal of Systematic Theology 23, no. 2 (April 2021): 156-76, https://doi.org/10.1111/ijst.12473.

${ }^{2}$ Will Bankston, 156-76.

${ }_{3}^{3}$ Merold Westphal juga berpendapat mengenai hal yang sama yaitu mengenai keberadaan dua kelompok yang berbeda ini. Kelompok yang pertama ia definisikan dengan kelompok arus modernisasi, dan kelompok satunya didefinisikan dengan kelompok posthumous dari filsuf Ateis (Nietzsche, Freud dan Heidegger). Menanggapi akan keterpisahan pemikiran antar dua kelompok ini, Westphal mengajukan pendapat yang menjembatani keduanya dengan melakukan rejection dan reconceptualizing terhadap kedua pemikiran tersebut. Merold Westphal, Overcoming Onto-Theology: Toward a Postmodern Christian Faith, 1st ed, Perspectives in Continental Philosophy, no. 21 (New York: Fordham University Press, 2001).

${ }^{4}$ Dalam artikelnya, Helseth memaparkan bukti-bukti sejarah yang menjelaskan lahirnya kelompok fundamentalis dari Old Princeton. Ia menelusuri sejarah mengenai kelompok ini dari abad 19 yang terus berkembang hingga saat ini. Ia menyebut kelompok fundamentalis yang sudah berkembang pada abad ini dengan istilah Neo-Fundamentalism. Paul Kjoss Helseth, "Re-Imagining' The Princeton Mind: Postconservative Evangelicalism, and The Rise of Neo-Fundamentalism," Journal of Evangelical Theological Society 45, no. 3 (2002): 427-50.

${ }^{5}$ Paul Kjoss Helseth, 433.

${ }^{6}$ Helseth mengatakan bahwa kelompok fundamentalis Old Princeton ini mendapat pengaruh besar dari Scottish Philosophy yaitu melalui pengajaran Thomas Reid. Dengan filsafat yang lebih empiris, menciptakan sebuah pemahaman akan kebenaran yang lebih kaku dan statis. Paul Kjoss Helseth, 433.

7 Yakub B. Susabda, Mengalami Kemenangan Iman: Integrasi Teologi Dan Psikologi (Jakarta: Literatur Perkantas, 2020), 194-95.

${ }^{8}$ Bob Altemeyer and Bruce Hunsberger, "Authoritarianism, Religious Fundamentalism, Quest, and Prejudice," International Journal for the Psychology of Religion 2, no. 2 (April 1992): 127, https://doi.org/10.1207/s15327582ijpr0202_5.

${ }^{9}$ Ruud Koopmans, "Religious Fundamentalism and Hostility against Out-Groups: A Comparison of Muslims and Christians in Western Europe," Journal of Ethnic and Migration Studies 41, no. 1 (January 2, 2015): 52, https://doi.org/10.1080/1369183X.2014.935307.

${ }^{10}$ Callum D. Scott, "Aquinas and Solovyov: Unified Christian Ontological-Epistemology in Critique of Epistemic Reductivism," Verbum et Ecclesia 39, no. 1 (September 11, 2018): 2-4, https://doi.org/10.4102/ve.v39i1.1891.

${ }^{11}$ Scott, 2.

${ }^{12} \mathrm{Scott}, 2$.

${ }^{13}$ Tegtmeyer juga memaparkan analisa yang seperti, yaitu bahwa kehadiran science secara empiris dan fenomenologis telah meniadakan konsep metafisika secara otomatis. Pemikiran metafisika selanjutnya dikembangkan oleh Heidegger menjadi sebuah konsep onto-theology yang berupaya menggantikan konsep metafisika Kristen tradisional. Tegtmeyer, Henning, "Why Christianity Needs Metaphysics," Tijdschrift Voor Filosofie, no. 3 (2018): 443-66, https://doi.org/10.2143/TVF.80.3.3285685.

${ }^{14}$ Scott, "Aquinas and Solovyov," 3.

${ }^{15}$ Gilson menekankan dalam bagian Preface dari bukunya bahwa pemikiran Aquinas mengenai teologi tidak dapat dipisahkan dari pemikiran filsafatnya dan begitu pula sebaliknya. Ia menekankan akan peran Aquinas sebagai teolog sekaligus filsuf. Etienne Gilson, Armand A. Maurer, and Laurence K. Shook, Thomism: The Philosophy of Thomas Aquinas, Etienne Gilson Series 24 (Toronto, Ont: Pontifical Institute of Mediaeval Studies, 2002), xiii.

${ }^{16}$ Dalam bukunya, Elders memaparkan dengan komprehensif mengenai keterkaitan antara Agustinus dan Aquinas. Berkaitan dengan konsep epistemologi, Elders berpendapat bahwa keberbedaan antar keduanya disebabkan oleh penggunaan sumber filsafat yang berbeda, Agustinus lebih mendekati filsafat Plato sedangkan Aquinas menggunakan filsafat Aristoteles. Leo J. Elders, Thomas Aquinas and His Predecessors: The Philosophers and The Church Fathers in His Works (Washington, D.C: The Catholic University of America Press, 2018), 104; 125-26. 
17 Augustine, Augustine De Doctrina Christiana, trans. R. P. H. Green, Oxford Early Christian Texts (Oxford [England]; New York: Clarendon Press, 1995).

${ }^{18}$ Augustine, I.II2.

${ }^{19}$ Leo J. Elders, Thomas Aquinas and His Predecessors: The Philosophers and The Church Fathers in His Works, 105.

${ }^{20}$ Gilson, Maurer, and Shook, Thomism, 106; St. Thomas Aquinas, Summa Theologica, vol. 1, Part I (Cosimo Classics, 2013), 1.12.12.

21 Dalam artikelnya, Aubry menganalisa konsep metafisika dari Aristotle dan Aquinas. Ia menyimpulkan bahwa satu sisi, Aquinas meresepsi konsep metafisika Aristotle, tapi di sisi lain, Aquinas melakukan beberapa perubahan dari konsep tersebut agar dapat sejalan dengan iman Kristen. Aubry, Gwenaëlle, "Ousia Energeia and Actus Purus Essendi," Tijdschrift Voor Filosofie, no. 4 (2015): 827-54, https://doi.org/10.2143/TVF.77.4.3139386.

${ }^{22}$ Gilson, Maurer, and Shook, Thomism, 137-74.

${ }^{23}$ Leo J. Elders, Thomas Aquinas and His Predecessors: The Philosophers and The Church Fathers in His Works, 106.

${ }^{24}$ St. Thomas Aquinas, Summa Theologica, 1, Part I:1, Part I:1, 2. 5, ad 1.

${ }^{25}$ St. Thomas Aquinas, 1, Part I:12.11. resp.

${ }^{26}$ James Dominic Rooney, "Being as Iconic: Aquinas on 'He Who Is' as the Name for God: Being as Iconic," International Journal of Systematic Theology 19, no. 2 (April 2017): 171, https://doi.org/10.1111/ijst.12212.

${ }^{27}$ Gregory P. Rocca, Speaking the Incomprehensible God: Thomas Aquinas on the Interplay of Positive and Negative Theology (Catholic University of America Press, 2012), 154-64, https://doi.org/10.2307/j.ctt2853rp.

${ }^{28}$ St. Thomas Aquinas, Summa Theologica, 1, Part I:1, 12, a, 5.

${ }^{29}$ St. Thomas Aquinas, 1, Part I:1. 2. 3 resp; Gilson, Maurer, and Shook, Thomism, 68-69.

${ }^{30}$ St. Thomas Aquinas, Summa Theologica, 1, Part I:1. 2.3 resp.

${ }^{31}$ Gilson, Maurer, and Shook, Thomism, 72.

32 Corey L. Barnes, "Ordered to the Good: Final Causality and Analogical Predication in Thomas Aquinas: Ordered to the Good," Modern Theology 30, no. 4 (October 2014): 433-53, https://doi.org/10.1111/moth.12055.

${ }^{33}$ Salah satu contohnya adalah Jean-Luc Marion yang adalah seorang filsuf katolik. Ia menjadi salah seorang tokoh yang menolak pembahasan mengenai Allah. Scott, "Aquinas and Solovyov," 3.

${ }^{34}$ St. Thomas Aquinas, Summa Theologica, 1, Part I:q. 45. a. 5.

${ }^{35}$ Abraham Mansbach, "Heidegger on the Self, Authenticity and Inauthenticity," S.H. Bergman Center for Philosophical Studies 40 (1991): 68.

${ }^{36}$ Mansbach, 70.

37 Penulis mengikuti penggunaan kata yang dianjurkan dan digunakan oleh Hardiman. F. Budi Hardiman, Heidegger Dan Mistik Keseharian: Sebuah Pengantar Menuju Sein Und Zeit (Jakarta: Kepustakaan Populer Gramedia, 2020), 53.

${ }^{38}$ F. Budi Hardiman, 53.

${ }^{39}$ F. Budi Hardiman, 55-57.

${ }^{40}$ Rae menekankan aspek relasi dengan being yang menjadi tema penting bagi Heidegger dalam membangun konsep mengenai Dasein. Gavin Rae, "Re-Thinking the Human: Heidegger, Fundamental Ontology, and Humanism," Human Studies 33, no. 1 (2010): 33.

41 Dalam upaya untuk menjelaskan fungsi Teologi bagi diri seseorang, Susabda mendefinisikan keseluruhan dan keutuhan diri dalam fungsi-fungsi psikologis yang dapat dimiliki oleh manusia. Yakub B. Susabda, Mengalami Kemenangan Iman: Integrasi Teologi Dan Psikologi, 47-59.

${ }^{42}$ Hubert L. Dreyfus and Mark A. Wrathall, eds., A Companion to Heidegger, Blackwell Companions to Philosophy 29 (Malden, MA: Blackwell Pub, 2005), 202; William Blattner, "Authenticity and Resoluteness," in The Cambridge Companion to Heideggers Being and Time, ed. Mark A. Wrathal, Cambridge Companion to Philosophy (Cambridge: Cambridge University Press, 2013), 332. Dalam pembacaan Blattner, ia mengatakan bahwa "Resoluteness, likewise, does not first take cognizance of a situation and put that situation before itself; it has put itself into that situation already. As resolute, Dasein is already taking action. Thus resoluteness is responsive to the immediate, concrete, and factical situation." 
43 F. Budi Hardiman, Seni Memahami: Hermeneutik Dari Schleiermacher Sampai Derrida (Yogyakarta: Kanisius, 2015), 97-130.

${ }^{44}$ F. Budi Hardiman, 109.

\section{DAFTAR PUSTAKA}

Altemeyer, Bob, and Bruce Hunsberger. "Authoritarianism, Religious Fundamentalism, Quest, and Prejudice.” International Journal for the Psychology of Religion 2, no. 2 (April 1992): 113-33.

Aubry, Gwenaëlle. “Ousia Energeia and Actus Purus Essendi.” Tijdschrift Voor Filosofie, no. 4 (2015): 827-54.

Augustine. Augustine De Doctrina Christiana. Translated by R. P. H. Green. Oxford Early Christian Texts. Oxford [England]; New York: Clarendon Press, 1995.

Bankston, Will. “'You Shall Be Actualized, for I Am Pure Actuality': Holiness and the Perfecting Relation of Grace." International Journal of Systematic Theology 23, no. 2 (April 2021): 156-76.

Barnes, Corey L. "Ordered to the Good: Final Causality and Analogical Predication in Thomas Aquinas: Ordered to the Good." Modern Theology 30, no. 4 (October 2014): 433-53.

Dreyfus, Hubert L., and Mark A. Wrathall, eds. A Companion to Heidegger. Blackwell Companions to Philosophy 29. Malden, MA: Blackwell Pub, 2005.

F. Budi Hardiman. Heidegger Dan Mistik Keseharian: Sebuah Pengantar Menuju Sein Und Zeit. Jakarta: Kepustakaan Populer Gramedia, 2020.

—. Seni Memahami: Hermeneutik Dari Schleiermacher Sampai Derrida. Yogyakarta: Kanisius, 2015.

Gilson, Etienne, Armand A. Maurer, and Laurence K. Shook. Thomism: The Philosophy of Thomas Aquinas. Etienne Gilson Series 24. Toronto, Ont: Pontifical Institute of Mediaeval Studies, 2002. 
Koopmans, Ruud. "Religious Fundamentalism and Hostility against Out-Groups: A Comparison of Muslims and Christians in Western Europe." Journal of Ethnic and Migration Studies 41, no. 1 (January 2, 2015): 33-57.

Leo J. Elders. Thomas Aquinas and His Predecessors: The Philosophers and The Church Fathers in His Works. Washington, D.C: The Catholic University of America Press, 2018.

Mansbach, Abraham. "Heidegger on the Self, Authenticity and Inauthenticity." S.H. Bergman Center for Philosophical Studies 40 (1991): 65-91.

Paul Kjoss Helseth. “'Re-Imagining” The Princeton Mind: Postconservative Evangelicalism, and The Rise of Neo-Fundamentalism." Journal of Evangelical Theological Society 45, no. 3 (2002): 427-50.

Rae, Gavin. "Re-Thinking the Human: Heidegger, Fundamental Ontology, and Humanism.” Human Studies 33, no. 1 (2010): 23-39.

Rocca, Gregory P. Speaking the Incomprehensible God: Thomas Aquinas on the Interplay of Positive and Negative Theology. Catholic University of America Press, 2012.

Rooney, James Dominic. "Being as Iconic: Aquinas on 'He Who Is' as the Name for God: Being as Iconic.” International Journal of Systematic Theology 19, no. 2 (April 2017): 163-74.

Scott, Callum D. "Aquinas and Solovyov: Unified Christian OntologicalEpistemology in Critique of Epistemic Reductivism.” Verbum et Ecclesia 39, no. 1 (September 11, 2018).

St. Thomas Aquinas. Summa Theologica. Vol. 1, Part I. Cosimo Classics, 2013.

Tegtmeyer, Henning. "Why Christianity Needs Metaphysics." Tijdschrift Voor Filosofie, no. 3 (2018): 443-66.

Westphal, Merold. Overcoming Onto-Theology: Toward a Postmodern Christian Faith. 1st ed. Perspectives in Continental Philosophy, no. 21. New York: Fordham University Press, 2001.

William Blattner. “Authenticity and Resoluteness.” In The Cambridge Companion to Heideggers Being and Time, edited by Mark A. Wrathal. Cambridge Companion to Philosophy. Cambridge: Cambridge University Press, 2013. 
Yakub B. Susabda. Mengalami Kemenangan Iman: Integrasi Teologi Dan Psikologi. Jakarta: Literatur Perkantas, 2020. 